\title{
Apparent Nutrient and Mineral Retention of Broilers Fed Periwinkle Flesh (Pachymelania aurita) and Palm Kernel Cake in Replacement to Fish Meal
}

\author{
B. I. Okon ${ }^{1} \&$ A. A. Ayuk ${ }^{1}$ \\ ${ }^{1}$ Department of Animal Science, Univerity of Calabar, Calabar, Nigeria \\ Correspondence: A. A. Ayuk, Department of Animal Science, Univerity of Calabar, Calabar, Nigeria. E-mail: \\ yinsajpcube2012@gmail.com
}

Received: Apil 17, 2014 Accepted: June 9, 2014 Online Published: August 15, 2014

doi:10.5539/jas.v6n9p177 URL: http://dx.doi.org/10.5539/jas.v6n9p177

\begin{abstract}
Fishmeal has contributed immensely as a rich protein source in the diets of poultry in Nigeria. However the cost of fishmeal has increased leading to high cost of poultry feed. This has fueled the search for cheaper alternative protein sources as a way of reducing cost. Two of such alternatives are periwinkle (Pachymelania aurita); a marine molluscs and palm kernel cake a by-product of oil palm. This study investigated the apparent nutrient and mineral retention of broilers fed periwinkle flesh (Pachymelania aurita) and palm kernel cake in place of fishmeal. One hundred and eighty (180) day-old Hyperco broiler chicks were randomly assigned to five dietary treatments 1, 2, 3, 4 and 5 with 3 replicates each and 12 chicks per replicate. Periwinkle flesh was fed in place of $2 \%$ fishmeal at 0,2.5 and 6.0\% inclusions respectively. Apart from Diet 1, which served as control, all others had in addition to maize $15 \%$ or $25 \%$ inclusion of palm kernel cake. The birds had access to water ad libitum. At 7 weeks of age, two experimental birds were randomly selected from each replicate and placed in metabolic cages; allowed to acclimatize for two days before metabolic trials.

The feeding of $25 \%$ Palm Kernel cake (PKC) along with $2 \%$ fishmeal or $6 \%$ periwinkle flesh resulted in significantly $(\mathrm{P}<0.05)$ higher $\mathrm{Ca}, \mathrm{Mg}$ and $\mathrm{K}$ retention when compared to the feeding of $15 \% \mathrm{PKC}$ or $25 \% \mathrm{PKC}$ along with a mixture of $1 \%$ fishmeal and $2.5 \%$ periwinkle flesh. Other minerals $\mathrm{P}, \mathrm{Mn}, \mathrm{Na}$, and $\mathrm{Fe}$, were not significantly affected. The apparent nutrient retention of broiler chickens was not significantly influenced.

Results of the study indicate that feeding $6 \%$ periwinkle flesh and $25 \%$ is suitable for replacing fishmeal and reducing maize thereby reducing cost of feed.
\end{abstract}

Keywords: fishmeal, nutrient, palm kernel cake, periwinkle and mineral retention

\section{Introduction}

The poultry industry in Nigeria has been on the decline since the advent of the petro-dollar. High cost of feed ingredients is one of the major factors responsible for the decline of the industry. This has caused instability in the livestock business in the past few years as many livestock farms are almost paralysed due to low or no profit margin (Iyayi et al., 2002). To overcome this challenge, the option of sourcing for cheap alternatives appears attractive (Ayuk et al., 2012).

Palm kernel cake and periwinkles are only two of an array of locally available raw materials that could be exploited for poultry feeds. The palm kernel cake is a blackish-brown product obtained after expressing oil from the palm kernel (Okon \& Ayuk, 2006). They are a cheap source of protein when compared to other conventional protein sources like fish meal (Okon \& Ayuk, 2007a). Palm kernel cake supplies both protein and energy its crude protein content of $18 \%$ classified it as a protein source of medium grade (Chin, 2001). Palm kernel cake is relatively cheap, relatively more easily available and virtually has no competition between man and farm animals (Kperegbeyi \& Akpobasa, 2008). Ofovbe (1987) had shown that palm kernel cake can be included up to $20 \%$ in broiler rations. When used in combination with supplementary L-lysine or DL-methionine, a good quality feed that improves performance of broiler chickens with least cost can be provided (Ofovbe, 1987). This feed resource should be fully utilized to reduce feed cost and also curb the problem of environmental pollution that accompanies its disposal (Anaeto et al., 2009). Palm kernel meal which is a by- product of palm kernel oil extraction was said to be palatable and satisfactory when used in poultry nutrition (Ugwuene, 2013). 
Periwinkles, snails, crabs, lizards and frogs are lesser protein sources that have hitherto been paid little or no attention as feed ingredients. Periwinkles (Tympanotus fuscatus, Pachymelania aurita and Littorina littorea) have been shown to be of high nutritive value, moreso than the hen's egg (Mba, 1980; Egwelle, 1982; Umoh et al., 1980 and Ndifon et al., 1997). They constitute relatively cheap source of animal protein in the South Eastern Nigeria (Adebayo-Tayo et al, 2006) and some riverine areas of West Arica (Ogungbenle \& Omowole, 2012). Their exposure to both marine and estuarine environments has all effects on the body burden of metal bioavailability from the natural as well as anthropogenic set up of the surroundings (Mohapatra, et al, 2009).

Despite the nutritive potentials of palm kernel cake and periwinkle, their optimal use in diets can better be evaluated by comparative utilization of their nutrients with a conventional protein source such as fishmeal. This paper was therefore designed to explore among others, the apparent nutrient and mineral retention of broilers fed periwinkle flesh as replacement for fishmeal.

\section{Materials and Methods}

\subsection{Materials}

A batch of 180-day-old Hyperco broiler chicks in the Teaching and Research farm of the University of Ibadan, South Western Nigeria, were randomly assigned to five dietary groups with three replicates each and twelve chicks per replicate. The feeding trial was based on the complete randomized design (CRD). These chicks were reared on deep litter throughout the eight weeks period of the study except for five days during the seventh week when metabolic studies were conducted. Known weights of experimental diets and fresh cool water were given ad libitum.

There were five experimental diets; composition of which is given in Table 1.

Diet 1 which was the Control contained 2\% fishmeal, but it had no palm kernel cake and periwinkle flesh. The second diet contained fishmeal a relatively low level of palm kernel cake $(15 \%)$ but no periwinkle flesh. Also, diet 3 contained fishmeal, no periwinkle flesh but a high level of palm kernel cake (25\%). Present in the fourth ration was a high level of palm kernel cake, relatively low levels of fishmeal and periwinkle flesh, namely: $1 \%$ and $2.5 \%$ respectively. The fifth diet contained $25 \%$ palm kernel cake, $6 \%$ periwinkle flesh and $0 \%$ fishmeal. Standard routine management practices and vaccinations were carried out.

Table 1. Gross composition of experimental diets

\begin{tabular}{cccccc}
\hline Ingredients (\%) & $\mathbf{1}$ & $\mathbf{2}$ & $\mathbf{3}$ & $\mathbf{4}$ & $\mathbf{5}$ \\
\hline Maize & 50.00 & 43.68 & 40.20 & 40.95 & 42.39 \\
Groundnut cake & 18.62 & 15.07 & 11.95 & 12.30 & 10.78 \\
Fish meal & 2.00 & 2.00 & 2.00 & 1.00 & 0.00 \\
Blood meal & 5.00 & 5.00 & 5.50 & 5.00 & 5.00 \\
Palm kernel cake & 0.00 & 15.00 & 25.00 & 25.00 & 25.00 \\
Periwinkle flesh & 0.00 & 0.00 & 0.00 & 2.47 & 6.00 \\
Dried brewer's grain & 8.98 & 8.00 & 8.00 & 2.83 & 6.00 \\
Wheat offal & 11.55 & 8.30 & 4.40 & 2.47 & 1.80 \\
Bone meal & 3.00 & 2.10 & 2.10 & 2.10 & 1.70 \\
Vitamin Premix* & 0.25 & 0.25 & 0.25 & 0.25 & 0.25 \\
DL-Methionine & 0.20 & 0.20 & 0.20 & 0.20 & 0.20 \\
L-Lysine & 0.00 & 0.00 & 0.00 & 0.30 & 0.04 \\
Salt & $\mathbf{0 . 4 0}$ & $\mathbf{0 . 4 0}$ & $\mathbf{0 . 4 0}$ & $\mathbf{0 . 4 0}$ & $\mathbf{0 . 4 0}$ \\
Total & 100.00 & 100.00 & 100.00 & 100.00 & 100.00 \\
\hline Analysed Nutrient & \multicolumn{5}{c}{ Composition of Diets } \\
\hline Crude protein & 23.09 & 23.02 & 22.97 & 23.01 & 22.99 \\
Crude fibre & 4.30 & 5.38 & 6.02 & 6.11 & 4.83 \\
Ether Extract & 4.23 & 4.49 & 4.64 & 4.52 & 4.37 \\
\hline
\end{tabular}




\begin{tabular}{cccccc}
\hline M.E.Kcal/Kg & 2800.06 & 2800.13 & 2800.22 & 2799.81 & 2800.28 \\
L-Lysin & 1.05 & 1.05 & 1.04 & 0.98 & 1.26 \\
DL-Methionine & 0.52 & 0.53 & 0.54 & 0.50 & 0.49 \\
Ca g/kg & 1.34 & 1.02 & 1.03 & 1.18 & 1.27 \\
Pg/kg & 0.66 & 0.53 & 0.52 & 0.46 & 0.43 \\
Protein, energy ratio & 121.27 & 121.64 & 121.9 & 121.68 & 121.80 \\
\hline
\end{tabular}

*The following were present per kg: Vitamin A 9,000.000 I. U., Vitamin D 1,280.000 I.U., Vitamin E 7000 I. U., Riboflavin 6,000 mg, Vitamin B 2,200 mg, Vitamin B B $_{5}$ 14,000 mg, Lysine 120,000 m/g, Methionine 65,000 mg, Chlorine chloride 240,000 mg, Mn 60,000 mg, Fe 35,000 mg, Cu 5,000 mg, Se 100 mg, Anti oxidant.

\subsection{Methods}

\subsubsection{Apparent Nutrient and Mineral Retention}

At 7 weeks of age, two experimental birds were randomly selected from each replicate and placed in metabolic cages. The birds selected were given two days to acclimatize in the metabolic cages after which they were given known weights of the experimental diets containing ferric oxide as a marker.

Droppings containing marker were collected for five days. During the period of collection, boric acid powder was sprinkled daily on the droppings to reduce loss of ammonia and hence nitrogen. On collection, the droppings were weighed fresh after feathers and other contaminants had been removed. The cleared droppings were then oven dried at $60{ }^{\circ} \mathrm{C}$ for 72 hours and then allowed to cool in a desiccator, weighed and milled.

The A.O.A.C. (1975) methods of analysis were used to determine the proximate components of the droppings.

Percentage retentions of nutrients and minerals including energy were calculated using the general formula of Maynard and Loosli, 1969:

$$
\frac{\mathrm{A} \times \mathrm{B}-\mathrm{C} \times \mathrm{D}}{\mathrm{A} \times \mathrm{B}} \times 100 \%
$$

Where

$\mathrm{A}=$ Feed intake during the period of metabolic study $(\mathrm{g})$;

$\mathrm{B}=$ Percentage of parameter in feed;

$\mathrm{C}=$ Dry weight of droppings voided (with marker) during the period of metabolic study;

$\mathrm{D}=$ Percentage of parameter in droppings.

\subsubsection{Statistical Analysis}

Data collected were subjected to the analysis of variance (ANOVA) method of Steel and Torrie (1960). Significant values were compared using the Duncan's multiple range test (1955).

\section{Results}

The percentage apparent nutrient retention is given in Table 2. Although the levels of nitrogen fat and ash retained were high, the levels of fibre and metabolizable energy retained were comparatively low. Dietary treatments did not affect the proximate nutrient retention of all birds $(\mathrm{P}>0.05)$.

Table 2. Apparent nutrient (\%) retention of experimental diets

\begin{tabular}{cccccc}
\hline \multirow{2}{*}{ Composition } & \multicolumn{5}{c}{ Diets } \\
\cline { 2 - 6 } & 1 & 2 & 3 & 4 & 5 \\
\hline Nitrogen & $68.74 \pm 2.08^{*}$ & $67.54 \pm 3.00$ & $67.12 \pm 2.67$ & $69.36 \pm 2.96$ & $70.43 \pm 0.85$ \\
Fat & $71.33 \pm 6.70$ & $69.59 \pm 6.46$ & $71.31 \pm 5.42$ & $70.67 \pm 6.82$ & $72.80 \pm 5.11$ \\
Fibre & $26.30 \pm 3.34$ & $25.02 \pm 3.15$ & $26.27 \pm 2.76$ & $25.13 \pm 1.37$ & $26.32 \pm 2.91$ \\
Ash & $66.45 \pm 1.49$ & $65.32 \pm 1.30$ & $66.41 \pm 1.81$ & $65.29 \pm 0.86$ & $66.71 \pm 2.11$ \\
Metabolizableenergy & $51.43 \pm 2.37$ & $52.01 \pm 2.98$ & $51.61 \pm 5.94$ & $51.68 \pm 4.98$ & $51.67 \pm 5.55$ \\
\hline
\end{tabular}

*: $\mathrm{P}>0.05$. 
The percentage apparent nutrient composition of droppings from the experimental birds is given in Table 3 . Table 4 presents the percentage mineral retention of the experimental birds. Dietary treatments did not affect $(\mathrm{P}>0.05)$ the percentage retention of $\mathrm{M} \mathrm{n}, \mathrm{Na}$ and $\mathrm{Fe}$ of the birds. But for phosphorus retention, similar retention occurred in birds fed either high fishmeal or high periwinkle flesh along with high palm kernel cake level. The recorded values were consistently higher than that of those fed lower palm kernel cake level with high fishmeal. The percentage mineral levels present in the collected droppings have been given in Table 5.

Table 3. Proximate composition (\%) of droppings from birds

\begin{tabular}{cccccc}
\hline Composition & \multicolumn{5}{c}{ Diets } \\
\cline { 2 - 6 } & 1 & 2 & 3 & 4 & 5 \\
\hline Nitrogen & $1.01 \pm 0.10^{*}$ & $1.06 \pm 0.14$ & $1.09 \pm 0.13$ & $1.09 \pm 0.16$ & $1.04 \pm 0.16$ \\
Ether Extract & $1.40 \pm 0.07$ & $1.41 \pm 0.25$ & $1.43 \pm 0.17$ & $1.48 \pm 0.19$ & $1.46 \pm 0.19$ \\
Fibre & $12.57 \pm 0.95$ & $12.7 \pm 0.36$ & $12.92 \pm 0.82$ & $12.79 \pm 0.71$ & $12.77 \pm 0.71$ \\
Ash & $21.93 \pm 2.50$ & $22.17 \pm 2.09$ & $22.90 \pm 2.56$ & $21.23 \pm 0.15$ & $21.77 \pm 3.00$ \\
Moisture & $39.71 \pm 1.25$ & $41.87 \pm 0.33$ & $40.18 \pm 1.74$ & $37.69 \pm 2.77$ & $38.07 \pm 2.12$ \\
Nitrogen Free Extracts & 18.08 & 15.23 & 15.76 & 20.00 & 19.43 \\
Gross energy (Kcal/kg) & $2.66 \pm 0.18$ & $2.58 \pm 0.16$ & $2.65 \pm 0.33$ & $2.63 \pm 0.27$ & $2.65 \pm 0.30$ \\
\hline
\end{tabular}

Table 4. Mineral Retention (\%) of experimental birds

\begin{tabular}{cccccc}
\hline \multirow{2}{*}{ Minerals } & \multicolumn{5}{c}{ Diets } \\
\cline { 2 - 6 } & 1 & 2 & 3 & 4 & 5 \\
\hline $\mathrm{Ca}$ & $67.27 \pm 5.68^{\mathrm{a}}$ & $53.74 \pm 4.12^{\mathrm{b}}$ & $65.33 \pm 5.51^{\mathrm{a}}$ & $55.33 \pm 1.53^{\mathrm{b}}$ & $66.36 \pm 5.06^{\mathrm{a}}$ \\
$\mathrm{P}$ & $61.39 \pm 3.85^{\mathrm{b}}$ & $61.09 \pm 4.35^{\mathrm{b}}$ & $62.50 \pm 4.17^{\mathrm{b}}$ & $62.70 \pm 5.99^{\mathrm{b}}$ & $66.67 \pm 6.29^{\mathrm{a}}$ \\
$\mathrm{Mg}$ & $64.81 \pm 4.24^{\mathrm{a}}$ & $59.80 \pm 4.49^{\mathrm{b}}$ & $64.81 \pm 4.24^{\mathrm{a}}$ & $63.96 \pm 4.15^{\mathrm{a}}$ & $65.76 \pm 5.63^{\mathrm{a}}$ \\
$\mathrm{Mn}$ & $60.53 \pm 2.29$ & $60.21 \pm 3.32$ & $60.59 \pm 4.78$ & $61.17 \pm 5.28$ & $61.48 \pm 4.07$ \\
$\mathrm{~K}$ & $66.67 \pm 5.13^{\mathrm{a}}$ & $55.56 \pm 11.11^{\mathrm{b}}$ & $63.16 \pm 7.90^{\mathrm{a}}$ & $59.05 \pm 4.36^{\mathrm{b}}$ & $64.96 \pm 1.48^{\mathrm{a}}$ \\
$\mathrm{Na}$ & $62.77 \pm 1.76$ & $61.40 \pm 1.78$ & $62.24 \pm 1.94$ & $62.19 \pm 1.85$ & $61.48 \pm 2.24$ \\
$\mathrm{Fe}$ & $67.31 \pm 2.59$ & $68.91 \pm 3.55$ & $68.10 \pm 1.73$ & $67.10 \pm 2.56$ & $67.35 \pm 1.23$ \\
\hline
\end{tabular}

Means with different superscripts on same row are significantly different $(\mathrm{P}<0.05)$.

Table 5. Minerals (\%) in droppings from experimental birds

\begin{tabular}{cccccc}
\hline Parameters & \multicolumn{5}{c}{ Diets } \\
\cline { 2 - 6 } & 1 & 2 & 3 & 4 & 5 \\
\hline Feed Intake (g) & $120.00 \pm 0.05^{*}$ & $120.00 \pm 0.05$ & $120.00 \pm 0.006$ & $120.00 \pm 0.04$ & $120.00 \pm 0.005$ \\
Droppings DM basis (g) & $41.33 \pm 5.03$ & $35.33 \pm 5.03$ & $34.67 \pm 2.31$ & $44.00 \pm 4.00$ & $44.00 \pm 4.03$ \\
$\mathrm{Ca}$ & $0.36 \pm 0.06$ & $0.45 \pm 0.04$ & $0.35 \pm 0.06$ & $0.45 \pm 0.02$ & $0.37 \pm 0.06$ \\
$\mathrm{P}$ & $0.2 \pm 0.002$ & $0.18 \pm 0.02$ & $0.18 \pm 0.02$ & $0.17 \pm 0.02$ & $0.13 \pm 0.03$ \\
$\mathrm{Mg}$ & $0.13 \pm 0.01$ & $0.14 \pm 0.01$ & $13.00 \pm 0.01$ & $0.13 \pm 0.02$ & $0.13 \pm 0.01$ \\
$\mathrm{Mn}$ & $75.0 \pm 4.35$ & $75.6 \pm 6.30$ & $73.33 \pm 8.89$ & $73.40 \pm 9.98$ & $74.33 \pm 7.86$ \\
$\mathrm{~K}$ & $0.13 \pm 0.02$ & $0.16 \pm 0.44$ & $0.17 \pm 0.04$ & $0.19 \pm 0.03$ & $0.15 \pm 0.03$ \\
$\mathrm{Na}$ & $183.00 \pm 8.56$ & $193.0 \pm 8.92$ & $185 \pm 9.53$ & $186.00 \pm 9.08$ & $193.00 \pm 11.21$ \\
$\mathrm{Fe}$ & $186.67 \pm 14.79$ & $178.67 \pm 20.43$ & $185.33 \pm 10.03$ & $190.00 \pm 14.82$ & $190.00 \pm 7.19$ \\
\hline
\end{tabular}

*: $\mathrm{P}>0.05$. 


\section{Discussion}

\subsection{Apparent Nutrient Retention}

Sundu et al. (2005) reported that though the amino acid content of palm kernel cake is low, its availability is very high, exceeding $85 \%$ and can serve as adequate replacement for some of the conventional feedstuff in poultry diet if adequately supplemented with animal protein or deficient amino acids. It would appear from the results obtained in this feeding trial that the feeding of $2 \%$ fishmeal or $6 \%$ periwinkle flesh along with $25 \%$ PKC did not significantly affect the percentage apparent nutrient retention of broiler chickens. Similar observations have been reported in the retention of fats, fibre, ash and energy when broiler birds were given either $2 \%$ fishmeal or $6 \%$ periwinkle flesh in palm kernel cake rations (Okon \& Ayuk, 2007b). However, high protein, fat and ash retention suggest high digestibility of the rations. These are comparably higher than results obtained for selected popular poultry feeds evaluated by Joseph et al. (1999). Anaeto et al. (2009) observed that palm kernel meal has good quality protein. Dietary protein plays a significant role in nitrogen retention and the level of protein intake influences nitrogen retention (Ani \& Okorie, 2013). According to Maynard and Loosli (2000), inadequate supply of dietary protein results in reduced nutrient retention. The High protein retention was an indication of adequate supply of dietary protein. This is important because retained proteins furnish the body with amino acids that are used for the synthesis of body protein including blood proteins (Bashar et al., 2010). It is also probable that the oil content of the rations could have enhanced retention. Oil reduces the rate of food passage through the gastrointestinal tract, which allows a better absorption of all nutrients present in the diet (Baião \& Lara, 2005). The presence of oil in broiler rations stimulated significantly better nutrient retention (Okon \& Ayuk, 2007b). Palm kernel cake contains varying amounts of oil (Arowora \& Tewe, 2003).

\subsection{Apparent Mineral Retention}

From the values obtained in this study, dietary treatments did not significantly affect the retention of $\mathrm{Mn}, \mathrm{Na}$ and Fe. The feeding of $25 \% \mathrm{PKC}$ along with $2 \%$ fishmeal or $6 \%$ periwinkle flesh resulted in higher $\mathrm{Ca}, \mathrm{Mg}$ and $\mathrm{K}$ retention in comparison with the feeding of $15 \%$ PKC or $25 \%$ PKC along with a mixture of $1 \%$ fishmeal and 2.5 $\%$ periwinkle flesh. This observation could be as a result of better availability of essential amino acids which resulted in better utilization of the feed (Mc Donald et al., 1995). Khadijat et al. (2012) reported better feed efficiency at $5 \%$ than at $2 \%$ fishmeal inclusion for broiler fed varying levels of palm kernel meal supplemented with different levels of fishmeal. The observed trend corroborates the reports of Sundu et al. (2005) that palm kernel cake diets should be supplemented with animal protein or deficient amino acids for optimum performance.

The indication therefore, would be that the feeding of $25 \%$ PKC along with $2 \%$ fishmeal or $6 \%$ periwinkle flesh significantly enhanced the retention of $\mathrm{Ca}, \mathrm{Mg}$ and $\mathrm{K}$. It is probable that there exists a mineral binding protein (for example $\mathrm{Ca}$ - binding protein) in fishmeal and periwinkle flesh, responsible for the increased absorption of these minerals, by the process of maintaining the mineral ions in soluble forms during the transfer of the minerals from the lumen of the intestine into the cell of the intestinal wall. These proteins also maintain the mineral ions in solution during the transfer across the serosa membrane. Vitamin-D increases the synthesis of these carrier proteins. Although the mineral profiles of the PKC, fishmeal and periwinkle were not shown, it appears that feeding $25 \%$ PKC along with $2 \%$ fishmeal or $6 \%$ periwinkle could supply adequate amounts of $\mathrm{Ca}$, $\mathrm{Mg}, \mathrm{K}$ and P. Adequate supply of these minerals given would allow for proper growth and development of the birds. There is a correlation between micronutrients, energy and broiler performance (Ayanwale \& Ogunmodede, 1999). Reduction in inclusion rates of fishmeal $1 \%$ and periwinkle $2.5 \%$ with either $15 \%$ PKC or $25 \%$ PKC caused significantly lower retentions of $\mathrm{Ca}, \mathrm{Mg}$ and $\mathrm{K}$. It suggests therefore that a combination of $6 \%$ periwinkle and $25 \%$ PKC can supply substantial amounts of nutrients and the minerals thereby reducing cost of purchasing fishmeal and maize.

\section{Conclusion}

Exploiting the possibility of utilizing periwinkle flesh in poultry feeds led to its being fed along with palm kernel cake to broiler chicks for eight weeks. There was no dietary effect on the percentage apparent nutrient and some mineral retention when broiler chickens were fed varying levels of PKC, fishmeal and periwinkle flesh. However, the results indicates that feeding 6\% periwinkle flesh and 25\% PKC in broiler diet gives apparent nutrient and mineral retention comparable to diets with $2 \%$ fishmeal.

\section{References}

Adebayo-Tayo, B. C., Onilude, A. A., Ogunjobi, A. A., \& Adejoye, D. O. (2006). Bacteriological and proximate analysis of periwinkles from two different creeks in Nigeria. World Applied Sciences Journal, 1(2), 87-91. 
Anaeto, M., Chioma, G. O., \& Omosebi, D. J. (2009). Palm kernel cake as substitute for maize in broiler finisher diet. International Journal of Poultry Science, $8(12), \quad$ 1206-1208. http://dx.doi.org/10.3923/ijps.2009.1206.1208

Ani, A. O., \& Okorie, A. U. (2013). Effects of processed castor oil bean (Ricinus communis L.) meal and supplementary dl- methionine on nutrient utilization by broilerchicks. The Journal of Animal \& Plant Sciences, 23(5), 1228-1235.

Arowora, K. A., \& Tewe, O. O. (2003). Serum biochemical parameters, apparent nutrient utilization and economy of production of growing pigs fed cassava based fibrous diets. Tropical Journal of Animal Science $6(2), 35-45$.

Association of Analytical Chemists. (1975). Official Methods of Analysis. Washington D.C: Association of Analytical Chemists.

Ayanwale, B. A., \& Ogunmodede, B. K. (1999). Growth and energy efficiency of birds fed different commercial premixes at two developmental stages. Nigerian Journal of Animal Production, 26, 43-47.

Ayuk, A. A., Anya, M. I., Okon, B. I., Wogar. G. S. I., Okon, B., \& Akpan, B. J. (2102). Performance and cost effectiveness of feeding Maize cob ash cocoa treated pod husk treated corn cob ash diet to weaner pigs (Large White X Landrace). Journal of Sustainable Tecnology, 3(2), 107-112.

Baião, N. C., \& Lara, N. R. C. (2005). Oil and fat in broiler nutrition. Brazilian Journal of Poultry Science, 7(3), 129-141.

Bashar, Y. A., Tukur, H. M., Sekoni, A. A., \& Hassan, W. A. (2010). Nutrient Retention and Haematological Indices of Broiler Starters Fed Lablab Seed Meal as the Source of Protein. Nigerian Journal of Basic and Applied Science, 18(2), 285-291.

Chin, F. Y. (2001). Palm Kernel Cake (PKC) as supplement for fattening and dairy cattle in Malaysia. In Feed Resources for S. E. Asia, Manado, Indonesia.

Duncan, D. B. (1955). Multiple range and F tests. Biometrics, 11, 1-42. http://dx.doi.org/10.2307/3001478

Egwelle, A. U. (1982). The chemical and biological evaluation of the nutritive value of some lesser known protein sources. Msc. Thesis, University of Ibadan, Nigeria.

Iyayi, E. A., Abu, O. A., \& Afolabi, K. D. (2002). Changes in the protein and fibre components of cassava and yam peels after solid-state fermentation by Aspergillus niger and Rhizopus sp. Research Communication Microbiology, 1, 32-39.

Joseph, J. K., Ijalana, O. O., \& Abu, O. A. (1999). Growth performance and carcass quality of broiler chickens as influenced by proprietary source of feed. Tropical Animal Production Investigation, 2, 103-109.

Khadijat, B. M., Enoch, O. O., \& Suleiman, B. E. (2012) Performance, carcass characteristics and blood composition of broilers fed varying levels of palm kernel meal (Elaise guinensis) supplemented with different levels of fishmeal. International Journal of Poultry Science, 11(1), 73-77. http://dx.doi.org/10.3923/ijps.2012.73.77

Kperegbeyi, J. I., \& Akpobasa, B. I. O. (2008). Effects of replacing soyabean meal and maize with palm kernel cake on the performance of finishing broiler chickens (pp. 500-501). Proceedings of the 33rd Annual Conference of the Nigerian Society for Animal Production.

Maynard, L. A., \& Loosli, J. K. (2000). Animal Nutrition. New York, NY: McGraw Hill Book Co.

Mba, A. U. (1980). Chemical composition of some local sources of protein foods for man. Nigerian Journal of Nutrition Science, 1, 142-147.

McDonald, P., Edwards, R. A., Greenhalgh, J. F. D., \& Morgan, C. A. (2002). Animal Nutrition. Edinburgh, U. K: Addison Wesley Longman Ltd.

Mohapatra, A., Rautray, T. R., Patra, A. K., \& Vijayan, V. (2009). Elemental Composition in mud crab Scylla serrate from Mahanadi estuary India:In situ irradiation analysis by external PIXE. Food and Chemical Toxicology, 47, 119-123. http://dx.doi.org/10.1016/j.fct.2008.10.016

Ndifon, P. M., Ayuk, A. A., Ebenso, I. E., \& Ndifon, C. O. (1997). Microbial flora and some biochemical constituent of periwinkle (Tympanotonus sp) flesh sold in Calabar market. Global Journal of Pure \& Applied Sciences, 3, 205-213.

Ofovbe, V. (1987). Metabolism of some divalent minerals by broilers fed palm kernel products and varying 
calcium to phosphorus ration. Ph.D Thesis, University of Ibadan, Nigeria.

Ogungbenle, H. N., \& Omowole, B. M. (2012). Chemical, functional and amino acid composition of periwinkle (Tympanotonus fuscatus var radula) meat. International Journal of pharmaceutical sciences review and research, 13(2), 128-132.

Okon, B. I., \& Ayuk, A. A. (2006). Carcass characteristics and meat quality of broilers fed periwinkle flesh (Pachymelania aurita), palm kernel cake and oil-based rations. Journal of the Science of Food and Agriculture, 86, 362-366. http://dx.doi.org/10.1002/jsfa.2356

Okon, B. I., \& Ayuk, A. A. (2007a). Effects of dietary supplementation of periwinkle flesh (Pachymelania aurita) on meat quality of broilers fed palm kernel cake based diets. Journal of Food, Agriculture and Environment, $5(3 \& 4), 330-333$.

Okon, B. I., \& Ayuk, A. A. (2007b). Nutrient and Mineral Retention of broilers fed Periwinkle Flesh (Pachymelania aurita). Medwell Online Agricultural Journal, 2(6), 646-650.

Steel, R. G. D., \& Torrie, J. H. (1960). Principles and procedures of statistics. McGraw Hill Book. Co. Inc, New York.

Sundu, B., Kumar, A., \& Dingle, J. (2005). Response of birds fed increasing levels of palm kennel meal supplemented with enzymes. Australia Poultry ScienceSymposium, 17, 227-228.

Ugwuene, M. C. (2013). Response of broiler turkeys to graded dietary levels of Palm Kernel Meal in replacement for maize. Nigerian Journal of Animal production, 40(2), 21-29.

Umoh, I. B., Ayalogu, E. O., \& Bassir, O. (1980). Evaluation of the nutritive value of some lesser known protein sources in Nigerian peasant diets. Ecology and Food Nutrition, 9, 81-86. http://dx.doi.org/10.1080/03670244.1980.9990585

\section{Copyrights}

Copyright for this article is retained by the author(s), with first publication rights granted to the journal.

This is an open-access article distributed under the terms and conditions of the Creative Commons Attribution license (http://creativecommons.org/licenses/by/3.0/). 